\title{
Hasta Hakları ve Ölme Hakkı: Masum Bir Hak ya da Suistimal*
}

Patient Rights and The Right to Die in Dignity: An Innocent Right or Abuse

Seçil Özçiftçi', Çağatay Üstün ${ }^{\mathrm{i}}$

Ege Üniversitesi Tıp Fakültesi Hastanesi Hemşiresi. İzmir Kâtip Çelebi Üniversitesi Sağıık Bilimleri Enstitüsü, Hemşirelik Esasları Anabilim Dalı Tezli Yüksek Lisans Öğrencisi https://orcid.org/0000-0002-7320-961X

ii Prof. Dr. Ege Üniversitesi Tıp Fakültesi, Tıp Tarihi ve Etik Anabilim Dalı https://orcid.org/0000-0001-7834-6616

\section{Sayın Editör;}

30 yıldan beri, Dünya Tıp Birliğinin 34. toplantısında hasta hakları olarak yayınladığı 1981 Lizbon Bildirgesinin içindeki bir ibarenin, yeniden etik ve hukuki açıdan değerlendirilmesi gerektiğine inanıyoruz. Bu bildirgede hasta için var olması önerilen 6 temel hakkın arasında beşinci maddede geçen "(Her) hastanın onurlu bir şekilde ölmeye hakkı vardır- The patient has the right to die in dignity) kavramı üzerinde çok fazla düşünülmeden, etik dayanaktan yoksun noktaları incelenmeden, hukuki bakış açısı ile değerlendirilmeye başlanmıştır. Onurlu ölme hakkının nasıl anlaşııması gerektiği hususu, felsefe, etik ve sosyoloji uzmanları tarafından ciddi bir şekilde ele alınmamış olduğu kanısını kuvvetlendiren en temel durum, yüzyıllardır açık ya da kapalı bir şekilde başvurulan ötanazi anlayışının 1981 yılındaki bu duyurudan sonra daha fazla konuşulur hale gelmesine bağlamak mümkündür.

Lizbon Bildirgesi orjinal metnindeki bu ibarenin bir "hak" yerine "ötanaziyi benimsetme ve benimseme" şekline dönüşmesinden endişe edildiği için, aynı bildirge 1995 Bali Bildirgesi'ne dönüşmüş, 2005'de yeniden revize edilmiştir. Halen kabul edilen metinde Lizbon Bildirgesi'ndeki beşinci madde değiştirilmesine rağmen, yine de onurlu ölme hakkını ortadan kaldırmamıştır. ${ }^{1,2}$

Türkiye'nin bu bildirgeyi kabul edilmesinden sonra, 1 Ağustos 1998'de 23420 sayılı Hasta Hakları Yönetmeliği hazırlanarak yayınlamıştır. Burada hastaya verilecek tıbbi özen ve temel bakım hizmetlerinin varlığı dikkati çekmekle birlikte, onurlu ölmeyi talep eden bir ibare bulunmamaktadır. Aksine íkinci Bölüm Sağlık Hizmetlerinden Faydalanma Hakkı'nda Ötanazi Yasağı başığı altında şöyle bir tanım yapılmıştır: Madde 13- Ötanazi yasaktır. Tıbbi gereklerden bahisle veya her ne suretle olursa olsun, hayat hakkından vazgeçilemez. Kendisinin veya bir başkasının talebi olsa dahil, kimsenin hayatına son verilemez. ${ }^{3}$ Bu yönetmelik 2014 yılında değişikliğe uğramasına karşın, Madde 13 değişmemiştir. ${ }^{4}$

Bu kavramı değerlendirirken Hollanda'da 2002 yılında belli şartlar dahilinde ötanazi'nin yasal bir hale dönüştüğünü (İstek Üzerine Hayata Son Verme ve İntihara Yardım Kanunu/Termination of Life on Request and Assisted Suicide Act) ${ }^{5}$, bunu Lüksemburg, Belçika, İsviçre gibi ülkelerin izlediğini biliyoruz. Ötanazi'nin ilk kez kabul edildiği ülke olan Hollanda'nın hukuksal geçmişine ve ceza kanunlarına bakıldığında, bu eylem cinayet suçuyla eş değer görülmektedir. Daha sonraki yıllarda değişen dünya koşulları, popülasyonun artması, toplumsal ve ahlâki değerlerin erozyona uğraması sebebiyle insan yaşamına saygı sorgulanmaya başlandı.

\footnotetext{
*Lokman Hekim Dergisi, 2019; 9(3):280-281

DOI: 10.31020/mutftd.579188

Geliş Tarihi - Received:18 Haziran 2019; Kabul Tarihi - Accepted: 05Temmuz 2019

Iletişim - Correspondence Author: Çağatay Üstün <cagatay.ustun@ege.edu.tr>
} 
İyileşme umudu az ya da hiç olmayan bir hastanın içinde bulunduğu durumun psikolojik yönden desteklenmesi ve hastalığın zorluğu ile mücadele ederken ona belirlenmiş bir protokol üzerinden bütüncül bir bakış açısını da kapsayan yardımın sağlanması gerekmektedir. Birey, dünyaya gelmeyi kendisi seçmediği gibi ölümünü de belirleme şansı olmamalıdır. Masum bir hak gibi önerilen Lizbon Bildirgesindeki bu ibarenin suiistimal boyutuna geçmemesi için, etik ilkeleri koruyan bir tıp mesleği oluşturmanın kaygısını hissetmek daha doğrudur.

\section{KAYNAKLAR}

1. World Medical Association Declaration of Lisbon on The Rights of The Patient. Erişim adresi: http://dl.med.or.jp/dlmed/wma/lisbon2005e.pdf, Erişim Tarihi: 10.05.2019

2. Editorial Team, Declaration of Lisbon on rights of the patient. Indian Journal of Medical Ethics 1996;4(2): 68.

3. Hasta Hakları Yönetmeliği. Erişim adresi: http://www.resmigazete.gov.tr/arsiv/23420.pdf, Erişim Tarihi: 10.05.2019

4. Hasta Hakları Yönetmeliğinde Değişiklik Yapılmasına Dair Yönetmelik. Erişim adresi: http://www.resmigazete.gov.tr/eskiler/2014/05/20140508-3.htm, Erişim Tarihi: 10.05.2019

5. Haan JD. The New Dutch Law on Euthanasia. Medical Law Review 2002;10:57-75. 